\title{
Pendidikan Moral pada Keluarga Muslim Perspektif Abdullah Nashih Ulwan dalam Kitab Tarbiyatul Aulad Fil Islam
}

\author{
Angi Ramdania Hermawan ${ }^{1}$, Oyoh Bariah ${ }^{2}$, Khalid Ramdhani ${ }^{3}$ \\ ${ }^{1}$ (Fakultas Agama Islam, Universitas Singaperbangsa Karawang, Indonesia). \\ ${ }^{2}$ (Fakultas Agama Islam, Universitas Singaperbangsa Karawang, Indonesia). \\ ${ }^{3}$ (Fakultas Agama Islam, Universitas Singaperbangsa Karawang, Indonesia). \\ * Corresponding Author. E-mail: aramdhaniah39@gmail.com
}

\begin{tabular}{|l|l|l|}
\hline Receive: 13/05/2021 & Accepted: 23/08/2021 & Published: 01/10/2021 \\
\hline
\end{tabular}

\begin{abstract}
Abstrak
Moral merupakan nilai penting dalam diri manusia. Melalui pendidikan dan pengajaran, nilai moral pada setiap individu akan berkembang dan membentuk karakter baik. Salah satu ulama yang memformulasikan konsep pendidikan moral adalah Abdullah Nashih Ulwan dalam kitabnya yang berjudul Tarbiyatul Aulad Fii al-Islam. Dalam pemikirannya, pendidikan moral diinternalisasikan dengan menumbuhkan rasa takut kepada Allah dan rasa diawasi oleh Allah yang menjadi benteng pemisah bagi individu untuk tidak melakukan keburukan. Selain itu, konsep ini menitikberatkan pada perhatian dan pengawasan orangtua terhadap beberapa perilaku anak yang merupakan substansi penting dalam pendidikan moral. Melalui penelitian study literature dengan pendekatan kualitatif deskriptif, peneliti bertujuan menggali konsep pendidikan moral perspektif Abdullah Nashih Ulwan secara lebih komprehensif dan detail. Hasil penelitian ini menjelaskan formula pendidikan moral pada keluarga muslim yang dapat diinternalisasikan oleh orangtua dalam mendidik moral anak.
\end{abstract}

Kata Kunci: Pendidikan Moral, Abdullah Nashih Ulwan, Keluarga Muslim

\begin{abstract}
Morals are an important value in humans. Through education and teaching, moral values in each individual will develop and establish good character. One of the scholars formulating the concept of moral education Is Abdullah Nashih Ulwan in his book Tarbiyatul Aulad Fii Al-Islam. In his thinking, a moral education is interned by instilling fear of god and the sense of divine supervision that serves as a bulging barrier for individuals to avoid doing bad. Furthermore, this concept focuses the attention and supervision of some of the child's behaviors that are essential for moral education. Through study study literature with a descriptive qualitative approach, researchers sought to delve into the moral education concept of abdullah nashih ulwan's perspective more comprehensive and detailed. This study explains the moral education formula for a Muslim family that can be interned by parents in educating children's morals.
\end{abstract}

Keywords: Moral Education, Abdullah Nashih Ulwan, A Muslim Family

\section{Pendahuluan}

Moral merupakan sekumpulan ajaran atau aturan tertulis maupun tidak tertulis yang menjadi guideline bagi manusia untuk menjadi manusia yang baik. Ukuran nilai moral pada diri manusia adalah baik dan buruk. Nilai moral tentu selaras dengan nilai-nilai Islam. Untuk itu, ajaran Islam menjadi acuan yang paling shahih dalam 
membina moral atau akhlak manusia. Dalam membina moral, Islam menaruh perhatian lebih pada eksistensi pendidikan dalam mengembangkan moral manusia. Ibnu Miskawaih (Al-Din, 2020) menegaskan bahwa moralitas akan berkembang jika mendapatkan pendidikan dan pengajaran. maka pendidikan moral merupakan bagian terintegrasi dalam pelaksanaan pendidikan, baik dalam pelaksanaan pendidikan Islam maupun pendidikan secara umum.

Menurut Muhammad Takdir Ilahi (2012) moral merupakan suatu aspek penting dalam kehidupan manusia yang menjadi tolak ukur kebaikan pada diri manusia, karena standar moral mengacu pada baik dan buruknya perilaku manusia. Menurut Frans Magnis Suseno (dalam Ilahi, 2012) "moral adalah sikap hati yang terungkap dalam sikap lahiriah." Sederhananya, moral diartikan sebagai watak, sikap, dan tingkah laku baik yang sesuai dengan hati nurani. Standar baik dan buruknya moral tidak hanya diartikan sebatas konsep moral yang diajarkan dalam komunitas tententu atau dalam satu suku tertentu, tetapi pada konsep moral yang lebih luas, yang terikat pada konsep moral yang diajarkan dalam agama dan juga hukum positif. Murtadha Muttahhari (dalam Machmud, 2014) mengatakan bahwa moral jika diartikan sebagai akhlak pada dasarnya adalah sesuatu yang mengajarkan manusia berhubungan, baik dengan Allah sebagai sang pencipta, maupun dengan sesama manusia dan juga lingkungannya.

Adapun, menurut Fatimah Ibda (2012) pendidikan moral adalah upaya sadar untuk membantu anak mendapatkan ilmu pengetahuan, keterampilan, sikap, dan nilai untuk mencapai kehidupan yang lebih baik dalam konteks kehidupan pribadi ataupun dalam kehidupan sosial bermasyarakat, yang mana nilai moralnya dapat bersumber dari nilai-nilai agama dan hukum positif yang berlaku di suatu wilayah tersebut. Ahmad Nawawi (2011) menjelaskan bahwa pendidikan moral merupakan upaya yang dilakukan oleh orang dewasa untuk menanamkan nilai ketuhanan, nilai estetik dan etik, baik dan buruk, dan segala perbuatan baik lainya kepada anak untuk mewujudkan kedewasaannya dan sadar akan kewajibannya. Kemudian, tujuan dari pendidikan moral adalah untuk membentuk kepribadian pada anak agar menjadi manusia yang baik dalam bermasyarakat dan bernegara (Rasimin et al., 2021). Dapat disimpulkan bahwa pendidikan moral merupakan upaya sadar yang dilakukan oleh pendidik untuk menginternalisasikan nilainilai moral kepada peserta didik dalam rangka mewujudkan kehidupan yang lebih baik sesuai dengan norma ketuhanan dan nilai positif yang berlaku.

Dalam pelaksanaannya, terdapat ruang lingkup yang menjadi fokus dari pendidikan moral baik yang dilakukan oleh orang tua, guru, maupun aktivis moral. Zuriah (dalam Rukiyati, 2017) menyatakan bahwa ruang lingkup pendidikan moral meliputi semua pelajaran yang berkaitan dengan segala hal yang menjadikan manusia bermoral baik bagi diri sendiri, sesama manusia, alam semesta, sampai kepada hubungan manusia dengan Tuhan. Ali Muhdi (2018) menjelaskan bahwa ruang lingkup pendidikan moral mencakup setiap persoalan yang terdapat hubungannya dalam memilih nilai yang diyakini sampai kepada nilai dan aturan etika yang prinsipnya bersifat umum.

Dalam konteks pendidikan Islam, adanya pendidikan moral berkaitan dengan definisi pendidikan Islam sebagai at-ta'dib yaitu suatu upaya pendidikan yang fokusnya adalah membentuk manusia yang beradab yang memiliki pemikiran dan perilaku berdasarkan prinsip-prinsip Islam (Ma'zumi et al., 2019). Hal ini sejalan dengan diutusnya Rasulullah Shallallahu alaihi wa sallam sebagai penyempurna akhlak bagi manusia. Dalam hadits Nabi Muhammad Shallallahu alaihi wa sallam bersabda:

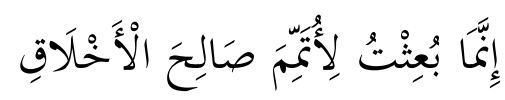

Artinya: "Sesungguhnya aku (Rasulullah "Siutus untuk menyempurnakan akhlaq yang baik." (HR. Ahmad) 
Terkait penafsirkan hadits diatas, Habib Umar menjelaskan pada laman harakah.id bahwa setiap manusia telah membawa akhlak sejak lahir, untuk kemudian disempurnakan dan dikembangkan dengan meneladani Rasulullah Shallallahu alaihi wa sallam. Dengan demikian, rujukan yang paling utama pendidikan moral dalam konteks akhlak adalah Rasulullah Shallallahu alaihi wa sallam.

Melihat perkembangan dan kemajuan zaman di era ini, modernisasi justru berdampak pada kemerosotan moral anak bangsa, termasuk juga moral para aparatur negara. Hal ini terlihat dari fenomena krirsis moralitas yang melanda Indonesia, seperti merebaknya Korupsi Kolusi Nepotisme (KKN), pergaulan bebas, makar, perkelahian, narkotika, tawuran antar pelajar, dan lain sebagainya. Wahidah (dalam Palinggi \& Ridwany, 2020) juga mengatakan bahwa sederatan permasalahan moral disebabkan karena adanya hegemoni dalam media massa. Tersebarnya berita palsu, ujaran kebencian, pornografi, penipuan, prostitusi online dan lain sebagainya merupakan dampak buruk dari kemajuan teknologi. Selain itu, berdasarkan data dari badan pusat statistik terkait angka kriminalitas di Indonesia sepanjang tahun 2019 tercatat sekitar 269.324 kejadian yang meliputi semua jenis perbuatan kriminal, baik yang sifatnya ringan maupun berat (Badan Pusat Statistik, 2020). Belum lagi, fenomena-fenomena yang muncul akibat krisis moralitas, misalnya krisis ekologi.

Dalam realitasnya, sistem pendidikan di Indonesia dianggap belum optimal dalam menanggulangi persoalan moral. Pelaksanaan pendidikan belum mencapai keberhasilan dalam mengoptimalkan ketiga aspek pembelajaran yang meliputi afektif, kognitif, dan psikomotorik, yang seharusnya ketiga aspek tersebut secara proporsional terinternalisasi dengan baik pada peserta didik dan menjadi satu kesatuan yang berkembang secara optimal. Pelaksanaan pendidikan di sekolah pun masih diarahkan untuk pemenuhan aspek kognitif dan aspek psikomotorik, sedangkan aspek afektif cenderung dinomor duakan. Sehingga pendidikan terkait nilainilai dan moral disekolah belum terealisasi dengan baik. Karena hal itu, sistem pendidikan di Indonesia dinilai sangat konservatif, mendahulukan nilai kognitif daripada nilai kejujuran yang merupakan value penting dalam diri seseorang (Montanesa et al., 2021). Padahal, di dalam undang-undang sistem pendidikan nasional termaktub tujuan utama pendidikan nasional, salah satunya adalah melahirkan peserta didik yang berakhlak karimah (mulia) dan bermoral.

Untuk itu, dalam menginternalisasikan nilai-nilai moral pada diri individu perlulah kerjasama yang baik antar lingkup pendidikan. Akan tetapi yang menjadi sangat berperan adalah orangtua, sebagaimana hadist Nabi Muhammad Shallallahu 'alaihi wa sallam yang diriwayatkan oleh At-tirmidzi dari Ayyub bin Musa dari bapaknya dan kakeknya bahwa Rasulullah Shallallahu alaihi wa sallam bersabda:

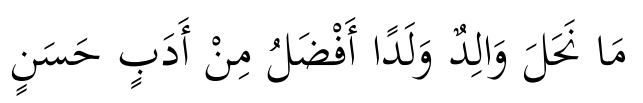

Artinya: "Tidak ada pemberian dari orangtua kepada anak yang lebih baik daripada adab yang baik." (HR. AtTirmidzi)

Orangtua sebagai pendidik pertama dan utama haruslah memaksimal perannya dalam mendidik anak, memberikan perhatian, dan juga pengawasan. Menurut Retno Dwiyanti (2013) pola asuh orangtua terhadap anak sangat berpengaruh terhadap perkembangan moral anak, orangtua yang kurang dalam memberikan perhatian, pengawasan, dan komunikasi dengan anak cenderung akan membuat anak terjerumus pada perilaku yang buruk. Selain itu, memberikan teladan yang baik juga merupakan kontribusi nyata dari orangtua dan semua pihak dalam meningkatkan moralitas pada anak (Budi, 2017).

Berdasarkan hal itu, maka penting bagi orangtua dalam memformulasikan suatu pola asuh yang dapat mendidik moral 
seorang anak sesuai dengan tuntunan Islam. Terdapat banyak pemikiran dan pendapat mengenai pola pendidikan moral pada keluarga muslim yang dapat diterapkan. Akan tetapi, yang menarik perhatian peneliti adalah pola pendidikan moral yang dikemukakan oleh Abdullah Nashih Ulwan.

Abdullah Nashih Ulwan adalah seorang da'i dan pendidik asal suriah yang concern dalam bidang pendidikan Islam dan seputar dakwah Islam. Pemikirannya tentang pendidikan moral terdapat dalam kitab yang merupakan karyanya yaitu Tarbiyatul Aulad Fii al-Islam. Dalam kitab tersebut, Abdullah Nashih Ulwan menjelaskan prinsip-prinsip fundamental pendidikan moral yang berlandaskan syariat Islam. Abdullah Nashih Ulwan (2020) menegaskan bahwa apabila keimanan dan muraqabatullah tertanam dengan baik pada sanubari seorang anak, maka hal itu menjadi benteng pemisah antara seorang anak dengan keburukan.

Berdasarkan hal itu, peneliti bertujuan menemukan dan memformulasikan konsep dan pola pendidikan moral berdasarkan perspektif Abdullah Nashih Ulwan. Peneliti menganggap bahwa pola dan konsep pendidikan moral perspektif Abdullah Nashih Ulwan mudah diterapkan oleh semua keluarga muslim, terkhusus orangtua sebagai pendidik dalam keluarga.

\section{Metode (15\%)}

Penelitian ini merupakan penelitian kualitatif deskriptif dengan pendekatan study literature atau studi kepustakaan. Penelitian studi kepustakaan merupakan jenis penelitian yang hanya menggunakan data yang berasal dari literature baik berupa teks maupun angka yang bersumber dari dokumen, buku, jurnal, majalah, dan lain sebagainya. Penelitian ini tujukan untuk menggali informasi dan menganalisis konsep pendidikan moral perspektif Abdullah Nashih Ulwan dalam kitab Tarbiyatul Aulad Fi al-Islam yang diterjemahkan oleh Arif Rahman Hakim sebagai sumber primernya dan analisis dokumen-dokumen lainnya yang berhubungan dengan konsep pendidikan moral dan pemikiran Abdullah Nashih Ulwan. Teknik analisis data yang digunakan dengan reduksi data, display data, dan penarikan kesimpulan.

\section{Hasil dan Pembahasan (70\%)}

\section{Biografi Abdullah Nashih Ulwan}

Abdullah Nashih Ulwan adalah seorang da'i dan pendidik asal suriah yang concern dalam bidang pendidikan Islam dan dakwah Islam. Beliau juga merupakan seorang doktor lulusan Universitas Al-Azhar dalam bidang fikih dan dakwah. Beliau adalah ulama yang lahir dari keluarga yang taat beragama pada tahun $1347 \mathrm{H} / 1928 \mathrm{M}$ di Desa Qadhi Askar, Kota Halab, Suriah. Beliau juga merupakan seorang keturunan Rasulullah Shallallahu alaihi wa sallam melalui nasab Al-Husain bin Ali bin Abi Thalib (Ulwan, 2020). Ayahnya bernama Said Ulwan yang merupakan seorang ulama dan juga tabib yang mashur dengan ramuan akar kayu dalam pengobatannya (Atabik \& Burhanuddin, 2015).

Dalam mengemban pendidikan formal pertamanya, Abdullah Nashih Ulwan mendapatkan pendidikan dasar di daerah kelahirannya yaitu di Desa Qadhi Askar. Selanjutnya, pada tahun 1934 M Abdullah Nashih Ulwan dimasukkan oleh Ayahnya untuk melanjutkan pendidikannya ke Khusruwiyyah untuk belajar ilmu-ilmu agama dan lulus pada tahun 1949 M. Pada saat masuk ke madrasah Khusruwiyyah, ia sudah mulai menghafal Al-Qur'an dan sudah cakap dalam berbahasa arab (Usman, 2018). Kemudian Abdullah Nashih Ulwan melanjutkan pendidikan Strata-1 nya di Universitas Al-Azhar Asy-Syarif pada Fakultas Ushuluddin dan lulus pada tahun 1952 M. Selang dua tahun dari pendidikan S1 nya, $1954 \mathrm{M}$ beliau telah menyelesaikan pendidikan S2 nya di Universitas yang sama (Ulwan, 2020).

Selama berkuliah di Universitas A1Azhar Asy-Syarif, Abdullah Nashih Ulwan 
mashur dikenal sebagai mahasiswa yang aktif dalam kegiatan dakwah Islam. Salah satunya, beliau bergabung pada Ikhwanul Muslimin sebagai organisasi yang bergerak dalam bidang dakwah Islam. Dalam organisasi tersebut, beliau kemudian berjuang bersama Syahid Abdul Qadir Audah, Sayyid Quthb, Syekh Abdul Baqi' Saqar (Iskandar, 2017).

Setelah menyelesaikan pendidikan S1 dan S2 nya, beliau kembali ke kota kelahirannya, Halab Suriah, untuk menjadi seorang pengajar di salah satu Sekolah Menengah Atas (SMA) sebagai pengajar bidang studi pendidikan Islam. Beliau adalah pengajar pertama yang menjadikan tarbiyatul Islam sebagai pelajaran dasar yang diajarkan di sekolah (Hani, 2019). Kemudian beliau beliau pergi Arab Saudi dan bekerja di Universitas Al-Malik Abdul Aziz, sekaligus melanjutkan pendidikan S3 nya pada program studi fikih dan dakwah, dan mendapatkan gelar doktor disana. Pada 29 Agustus 1987 M/5 Muharram $1398 \mathrm{H}$ beliau wafat di Jeddah dan dimakamkan di Mekah (Ulwan, 2020).

Semasa hidupnya, beliau berguru pada banyak ulama dan guru besar. Syaikh Raghib Ath-Thabbakh, Ahmad Asy-Syama, dan Izzudin Al-Bayyanuni adalah guru Abdullah Nashih Ulwan selama menempuh pendidikan menengahnya di Khusruwiyyah. Dan semasa hidupnya beliau telah membuat lebih dari 43 karya tulis berupa kitab (Lubis, 2018).

\section{Konsep Pendidikan Moral pada Keluarga Muslim Perspektif Abdullah Nashih Ulwan dalam Kitab Tarbiyatul Aulad Fii al-Islam}

Pendidikan Islam merupakan pendidikan kompleks dan multidimensional yang merupakan manifestasi long life education. Untuk itu, tanggungjawab pendidik tidak hanya sebatas transfer knowladge yang berkaitan dengan ajaran Islam, akan tetapi bertanggungjawab menjadikan didikannya sebagai spiritual person dan hamba Allah yang bertakwa. Salah satu dari tanggungjawab pendidik khususnya orangtua adalah memberikan pendidikan moral. Pendidikan moral sudah seyogyanya menjadi tanggungjawab besar bagi orangtua, karena internalisasi nilai-nilai Islam haruslah ditanamkan sedini mungkin, agar membentuk suatu pola atau kebiasaan baik.

Dalam kitab Tarbiyatul Aulad karya Abdullah Nashih Ulwan dijelaskan konsep pendidikan moral dalam Islam secara rinci berdasarkan apa yang diperintahkan oleh Allah Subhanahu wa ta'ala. Abdullah Nashih Ulwan mendefinisikan pendidikan moral sebagai pendidikan yang berisi sekumpulan sikap, watak, dan dasar-dasar dalam pendidikan moral yang dijadikan panduan tingkah laku dalam kehidupan sehari-hari bagi individu dari usia tamyiz sampai dengan mukallaf.

Dalam mendidik moral anak, orangtua harus terlebih dahulu memberikan dan menanamkan pendidikan Iman. Pendidikan Iman menjadi wasilah bagi keberhasilan proses internalisasi nilai-nilai moral pada diri individu. Watak dan akhlak yang baik merupakan buah keimanan dari ajaran dan nilai agama yang terinternalisasi dengan benar. Mendidik anak dengan aqidah yang benar, menumbuhkan rasa takut kepada Allah, rasa diawasi oleh Allah, senantiasa bertawakal kepada Allah, dan meminta pertolongan hanya kepada Allah adalah benteng pemisah bagi seorang anak dari akhlak yang tercela.

Dalam hadits yang diriwayatkan oleh Al-Baihaqi dari Ibnu Abbas bahwa Rasulullah Shallallahu alaihi wasallam bersabda:

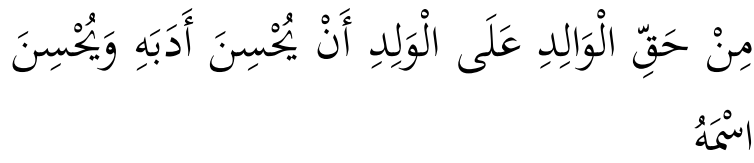

Artinya: "Yang termasuk hak dari seorang anak atas orangtuanya adalah mengajarinya adab dan memberinya nama yang baik." (HR. Al-Baihaqi)

Dalam melaksanakan kewajibannya terhadap anak, orangtua bertanggungjawab dalam mendidik lisan-lisan anak dari perkataan yang tercela, mendidik tingkah 
lakunya agar terhindar dari akhlak yang buruk, dan berkewajiban menumbuhkan rasa kemanusiaan pada diri anak.

Dalam pendidikan Islam, perhatian dan pengawasan orangtua menjadi faktor utama berhasilnya pendidik dalam mendidik anak. Abdullah Nashih Ulwan menjelaskan empat perilaku yang harus senantiasa diperhatikan dan diawasi oleh orangtua, diantaranya sebagai berikut:

a. Sifat suka berdusta atau berbohong

Berbohong merupakan akhlak mazmumah (tercela). Seorang pembohong atau pendusta digolongkan oleh Allah sebagai seorang munafik, ditulis sebagai seorang pembohong dihadapan Allah, dan terdapat murka Allah dan azab yang pedih bagi mereka. Berbohong merupakan sifat yang sudah mengakar dalam kehidupan bermasyarakat. Untuk itu, wajib bagi orangtua memformulasikan metode untuk mengjauhkan anak-anaknya dari sifat suka berbohong. Abdullah Nashih Ulwan menjelaskan metode dalam mendidik anak agar tidak menjadi seorang pendusta atau pembohong, yaitu sebagai berikut:

1. Menjauhkan anak-anak dari para pendusta atau pembohong.

2. Melarangnya dari perbuatan dusta dan berikan alasan mengapa perbuatan tersebut merupakan perbuatan yang terlarang, serta jelaskan akibat dari perbuatan dusta atau bohong.

3. Berikan teladan yang baik pada anak dengan tidak membohonginya dalam keadaan dan dengan alasan apapun, termasuk memotivasinya, menenangkannya, atau bahkan hanya sekedar candaan. Membohonginya sama saja dengan membiasakannya berbohong.

b. Sifat mencuri

Mencuri yang dimaksud disini ialah segala perbuatan yang sifatnya mengambil hak orang lain, menipu, dan berbuat curang. Abdullah Nashih Ulwan menegaskan bahwa untuk mencegah perilaku ini, rasa diawasi oleh Allah merupakan hal fundamental yang harus tertanam dengan benar. Orangtua bertanggungjawab memberikan pemahaman bahwa segala hal yang dihasilkan dari perilaku mencuri adalah haram dan akibat dari perilaku ini hanyalah keburukan, serta tunjukkan apa yang Allah janjikan terhadap orang yang dapat menghindarkan dirinya dari sifat mencuri dan apa yang Allah janjikan terhadap para pencuri.

c. Sifat suka mencaci dan mencela

Abdullah Nashih Ulwan mengemukakan dua penyebab seorang anak memiliki sifat suka mencaci dan mencela. Pertama, contoh atau teladan yang buruk. Kedua, lingkungan yang rusak. Dalam hal ini tanggungjawab yang harus dilaksanakan oleh orangtua mencakup:

1. Orangtua bertanggungjawab memberikan teladan yang baik dengan menjaga lisan dan memilah serta memilih kata-kata dalam berbicara.

2. Orangtua juga harus memperhatikan lingkungan pergaulan anak dan menghindarkannya dari bergaul dijalanan.

3. Orangtua bertanggungjawab memberikan pemahaman kepada anak mengenai dampak buruk dan bahaya lisan yang dapat mengahancurkan kehidupan sosial individu yang bersangkutan.

4. Orangtua juga bertanggungjawab dalam menunjukkan dalil akan perilaku mencaci dan mencela mencakup janji Allah bagi individu yang mampu menjaga diri dari perbuatan ini dan ancaman bagi individu yang tidak dapat menghindari dari perilaku ini.

d. Kenakalan dan penyimpangan

Kini, kenakalan dan penyimpangan menjadi fenomena yang sangat melekat dimasyarakat. Para pemuda dan pemudi cenderung mengikuti hawa nafsunya untuk kesenangan tanpa memperhatikan batasbatas syariat Islam. Dalam hal ini Abdullah Nashih Ulwan menegaskan bahwa pemuda 
dan pemudi yang kalah adalah mereka yang mengikuti erotisisme zaman dan pergaulan bebas.

Untuk mencegah empat perilaku yang dijelaskan diatas, Abdullah Nashih Ulwan memformulasikan langkah-langkah strategis yang benar dalam mendidik anak agar memiliki moralitas yang baik adalah sebagai berikut:

a. Mengajarkan anak memilah dan memilih tindakan supaya tidak ikut-ikutan atau taqlid buta dalam merespon perkembangan zaman.

Orangtua hendaknya melakukan seleksi terhadap pembaharuan dan kemajuan zaman yang ditawarkan, mengajarkan anak apa yang boleh diambil dan tidak boleh diambil olehnya dari apapun yang ditawarkan dizaman ini. Abdullah Nashih Ulwan menjelaskan terdapat dua perkara yang harus diperhatikan oleh orangtua yaitu mencakup:

1. Setiap muslim atau muslimah boleh mengambil ilmu yang bermanfaat dari perkembangan zaman yang ditawarkan.

Orangtua boleh mengajarkan kepada anak ilmu-ilmu selain ilmu syariat, seperti ilmu pengetahuan alam, teknologi, arsitektur, astronomi, dan ilmu-ilmu bermanfaat lainnya. Sebagaimana hadits Nabi Shallallahu 'alaihi wa sallam, dari Al-Askari dan Al-Qadha'i Rasulullah Shallallahu 'alaihi wa sallam bersabda:

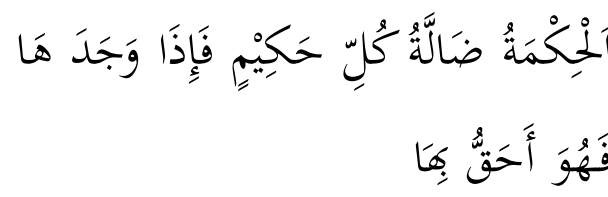

Artinya: "Al-Hikmah (ilmu pengetahuan) adalah barang yang hilang dari seorang bijak, maka barangsiapa yang menemukannya maka dialah yang berhak memilikinya." (H.R. At-Tirmidzi)

Jadi, apabila konteksnya adalah mengambil ilmu yang bermanfaat dari kemajuan di era ini dan ilmu tersebut tidak melanggar syariat Islam, maka boleh bagi seorang muslim untuk mempelajari, mengambil, dan memanfaatkannya.

2. Setiap muslim atau muslimah tidak boleh mengikuti akhlak atau perilaku orang-orang kafir.

Dalam mendidik moralitas
anak, $\quad$ orangtua hendaknya

memperhatikan akhlak, tingkah laku, habits, gaya hidup dan penampilan agar tidak ikut-ikutan pada segala hal buruk yang dibawa oleh dunia barat yang dapat menghancurkan ruhiyah, iradah, dan kemuliaan akhlak seorang muslim.

b. Mencegah anak agar tidak tenggelam dalam kesenangan yang menipu.

Dalam kehidupan sehari-hari, hendaknya orangtua membiasakan anak hidup dalam kesederhanaan dan mensyukuri apa yang dimilikinya. Dan orangtua tidak membiasakan anak hidup berlebihan atau bermewah-mewahan, sehingga tidak menyebabkan anak terus mengikuti hawa nafsunya untuk larut dalam kesenangan dan kemewahan. Abdullah Nashih Ulwan menegaskan bahwa perilaku yang disebutkan diatas dapat menggelincirkan anak ke dalam kesesatan dan penyimpangan. Dalam hadits Rasulullah Shallallahu alaihi wa sallam yang diriwayatkan oleh Imam Ahmad dan Abu Nu'aim dari Mu'adz bin Jabal disebutkan bahwa:

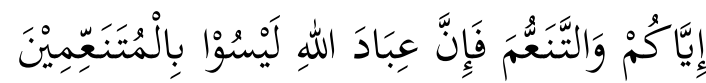

Artinya: "Janganlah kamu bermewah-mewahan karena sesungguhnya hamba-hamba Allah itu bukanlah yang suka bermewah-mewahan." (HR. Imam Ahmad dan Abu Nu'aim)

c. Melarang anak mendengar musik yang melalaikan dan nyanyian yang mengandung pornografi.

Menurut Abdullah Nashih Ulwan mendengarkan sesuatu yang diharamkan oleh Allah akan berpengaruh pada moral anak, mendorongnya pada perbuatan berdosa, dan cenderung akan mengikuti syahwat dan hawa nafsunya. Hal didasarkan pada hadits Nabi yang melarangnya. 
Diriwayatkan oleh At-Tirmidzi dari Abu Musa Al-Asy'ari bahwa Rasulullah Shallallahu alaihi wa sallam bersabda:

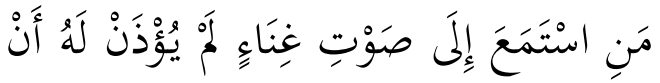

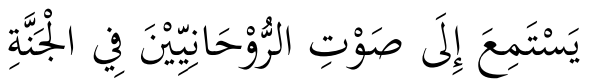

Artinya: "Barangsiapa yang gemar mendengarkan suara nyanyian, maka ia tidak akan diizinkan mendengarkan suara ar-ruhaniyyin di surga." (HR. At-Tirmidzi)

d. Melarang anak laki-laki bergaya dan berlagak seperti perempuan dan sebaliknya.

Abdullah Nashih Ulwan menegaskan bahwa perilaku ini termasuk ke dalam bentuk penyimpangan yang membawa umat manusia pada kerusakan dan dosa. Sebagaimana yang telah dijelaskan dalam hadits nabi, Abdullah Nashih Ulwan menegaskan kembali akan larangan mengenakan rambut palsu, memakai kain sutra bagi laki-laki, memakai emas bagi laki-laki, perempuan yang berpakaian tetapi telanjang, dan lain sebagainya. Dalam hal ini, hendaknya orangtua memperhatikan pola tingkah laku anak dan mengajarkannya kemampuan okupasional sesuai dengan gendernya.

e. Melarang anak memperlihatkan dan menanggalkan auratnya.

Abdullah Nashih Ulwan menegaskan kepada para pendidik untuk memerintahkan anak-anak perempuan mereka menutup auratnya, sebagainya Allah berfirman dalam surah Al-Ahzab ayat 59 sebagai berikut:

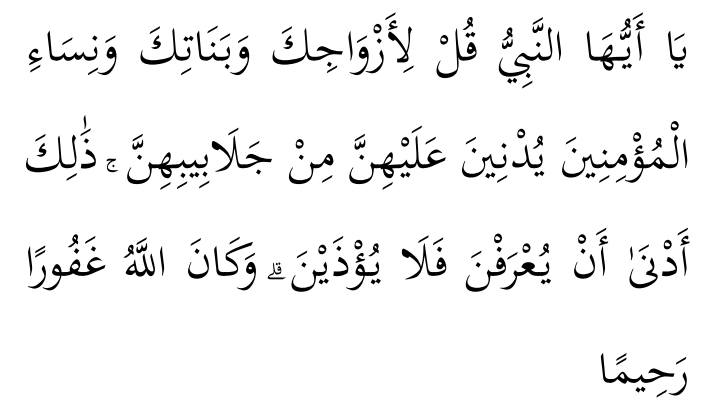

Artinya: "Hai Nabi, katakanlah kepada itri-istrimu, anak-anak perempuanmu, dan istri-istri orang mukmin, 'Hendaklah mereka mengulurkan jilbabnya ke seluruh tubuh mereka.' Yang demikian itu supaya mereka lebih mudah untuk dikenal, karena itu mereka tidak diganggu. Dan Allah adalah Maha Pengampun lagi Maha Penyayang." (QS. Al-Ahzab: 59)

Berdasarkan penafsiran dari para Imam mujtahid dan para fuqoha, Abdullah Nashih Ulwan menyimpulkan dan membaginya menjadi dua pendapat. Pertama, seluruh tubuh perempuan adalah aurat termasuk wajah dan wajib menutupnya. Kedua, para fuqoha hanafiyah menjelaskan bahwa wajah bukan merupakan aurat dan boleh membuka wajah apabila tidak mengundang fitnah, akan tetapi sebagai langkah preventif untuk mencegah fitnah dan kerusakan, maka sebaiknya wajah juga ditutup.

f. Melarang anak perempuan tabarruj (berhias) dan memamerkan kecantikannya.

Dalam hal ini, Abdullah Nashih Ulwan menjelaskan satu keterangan atau dalil yang menjadi dasar dilarangnya perbuatan ini untuk menjaga moral atau akhlak seorang muslimah. Keterangan itu terdapat dalam surah Al-Ahzab ayat 33 yaitu:

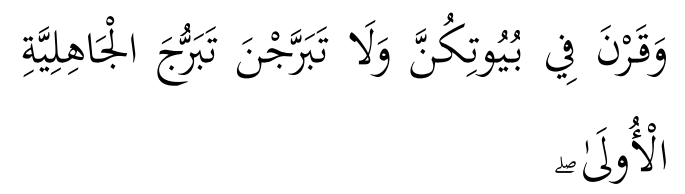

Artinya: "Dan hendaklah kamu tetap dirumahmu dan janganlah kamu berhias dan bertingkah laku seperti orangorang jahiliyah..” (QS. Al-Ahzab: 33)

g. Melarangnya ikhtilath

Larangan bercampur antara lakilaki dan perempuan (ikhtilath) menjadi langkah preventif dan solusi untuk menghindari kerusakan akibat seseorang yang tidak bisa menjaga pandangannya. Untuk itu, orangtua hendaknya lebih memperhatikan bagaimana pergaulan anaknya antara laki-laki dengan perempuan. 
Larangan ini telah disebutkan dalam surah An-Nur ayat 30 yaitu sebagai berikut:

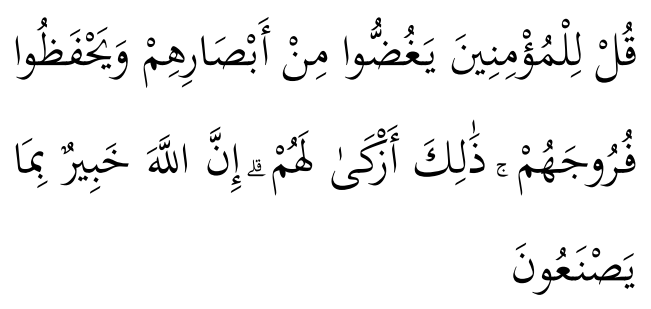

Artinya: "Katakanlah kepada orang laki-laki yang beriman, hendaklah mereka menahan pandangannya dan memelihara kemaluannya. Yang demikian itu adalah lebih suci bagi mereka. Sesungguhnya Allah Maha Mengetahui apa yang mereka perbuat." (QS. An-Nur: 30)

h. Melarang anak melihat hal-hal yang diharamkan

Dalam mendidik anaknya, orangtua haruslah mengajarkan kepada anaknya apa yang halal baginya dan apa yang haram baginya untuk dilihat, didengar, dan diucapkan. Hal ini berlandaskan pada firman Allah dalam surah Al-Isra ayat 36 yaitu:

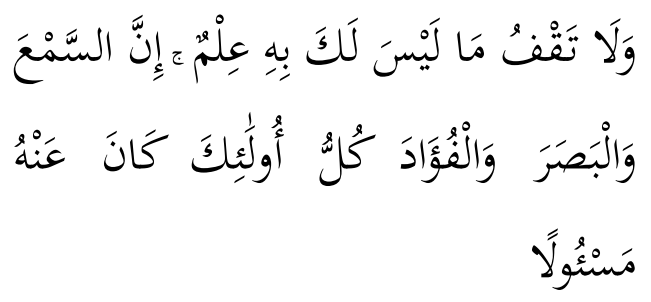

Artinya: "Dan janganlah kamu mengikuti apa yang kamu tidak mempunyai pengetahuan tentangnya. Sesungguhnya pendengaran, penglihatan dan hati, semuanya itu akan diminta pertanggungan jawabnya." (QS. Al-Isra: 36)

Adapun apabila ditemukan anakanak yang telah rusak moralnya, Abdullah Nashih Ulwan menegaskan faktor-faktor yang menjadi penyebab rusaknya moral seorang anak, yaitu diantaranya:

a. Lingkungan

Lingkungan bermain dan bergaul sangat mempengaruhi tumbuh kembang seorang anak. Lingkungan yang buruk akan membuat anak berperilaku buruk apalagi tanpa pengawasan yang ketat dari orangtua. Untuk itu, hendaknya orangtua menjauhkan anak-anaknya dari lingkungan yang buruk. Selain itu, dewasa ini, internet menjadi lingkungan pendidikan yang paling dekat dengan anak, hendaknya orangtua melakukan filterisasi informasi yang diakses oleh anak-anaknya di lingkungan digital ini.

b. Tontonan dan bacaan

Apa yang ditonton dan dibaca oleh anak merupakan konsumsi bagi jiwanya, tentunya akan berpengaruh pada tingkahlakunya. Untuk itu, orangtua hendaknya tidak membiarkan anak menonton film-film yang mengandung kekerasan, perkelahian, kebencian, erositisme, stereotip, rasisme dan film yang mengandung perilaku buruk lainnya. Selain itu, orangtua juga hendaknya memberikan perhatian pada buku-buku yang dibacanya dan pastikan tidak mengandung hal-hal buruk yang disebutkan diatas. Kini, anakanak juga suka bermain games online, banyak game online yang mengandung kekerasan dan perkelahian, maka dari itu orangtua juga harus memperhatikan game yang dimainkan oleh anak-anaknya.

c. Pelanggaran syariat

Orangtua tidak sepatutnya membiarkan anak-anaknya melanggar syariat Islam. Membiarkannya saat meninggalkan sholat dan puasa wajib, membiarkannya saat menanggalkan auratnya, tabarruj, ikhtilat dan memaklumi anak-anaknya saat mereka berdalih tidak menjalankan syariat Islam tanpa adanya udzur syar'i merupakan ketersengajaan menghancurkan moral anak yang dilakukan oleh orangtua.

d. Pengawasan

Pengawasan adalah hal penting yang wajib dilakukan oleh orangtua terhadap anak-anaknya. Apabila orangtua tidak melakukan pengawasan terhadap pergaulan dan kegiatan anak-anaknya, dikhawatirkan anak-anaknya melakukan hal-hal buruk yang dilarang oleh agama, sebagai contoh fenomena marrige by 
Jurnal Edumaspul, 5 (2), Year2021 - 821

(Angi Ramdania Hermawan ${ }^{1}$, Oyoh Bariah ${ }^{2}$, Khalid Ramdhani)

accident (MBA), narkoba, tawuran antar pelajar, pencurian, dan lain sebagainya, itu semua terjadi karena kurangnya pengawasan dari orangtua.

\section{Kesimpulan}

Berdasarkan penelitian yang telah dilaksanakan dapat ditarik kesimpulan bahwa pendidikan moral pada keluarga muslim dalam perspektif Abdullah Nashih Ulwan menitikberatkan pada peran orangtua dalam memberikan perhatian dan pengawasan terhadap empat perilaku utama yang substansial bagi suatu nilai moral yaitu sifat suka berbohong atau berdusta, mencuri atau mengambil hak orang lain, mencaci atau mencela, dan kenakalan/penyimpangan. Tidak hanya itu, orangtua juga haruslah memberikan perhatian dan pengawasan pada lingkungan, tontonan, dan pelanggaran syariat. Selain itu, untuk mencegah perilaku yang dapat merusak moralitas seseorang, maka terdapat langkah-langkah yang harus ditempuh oleh orangtua dalam mendidik moral anak yaitu memilah dan memilih perilaku dan tidak bertaklid buta pada perkara-perkara akidah, akhlak, dan syariat; mencegah anak agar tidak tenggelam pada kesenangan yang menipu; melarangnya mendengarkan musik dan nyanyian yang mengandung syahwat dan pornografi; melarang anak memperlihatkan dan menanggalkan auratnya; anak laki-laki tidak menyerupai dan berlagak seperti perempuan ataupun sebaliknya; tidak tabarruj dan memamerkan kecantikan; tidak ikhtilath; dan melarangnya melihat dan melakukan perkara-perkara yang diharamkan. Adapun, internalisasi pendidikan iman menjadi langkah utama dalam mendidik moral anak, karena keimanan kepada Allah dan rasa muraqabatullah (diwasi oleh Allah) menjadi benteng pemisah seorang anak dari keburukan akhlak.

\section{Daftar Pustaka}

Abdullah Nashih Ulwan. (2020). Tarbiyatul
Aulad Fii Al-Islam (Pendidikan Anak

dalam Islam). Insan Kamil Solo.

Al-Din, N. J. (2020). Ibnu Miskawaih

Pendidikan Percerdasan Spiritual.

Diomedia.

Atabik, A., \& Burhanuddin, A. (2015).

Konsep Nashih Ulwan tentang

Pendidikan Anak. Elementary, 3(2).

Badan Pusat Statistik. (2020). Statitik

Kriminal 2020. BPS RI.

Budi, I. (2017). Pengaruh Pengetahuan

Moral Terhadap Perilaku Moral Pada

Siswa Smp Negeri Kota Pekan Baru

Berdasarkan Pendidikan Orangtua.

Journal of Chemical Information and

Modeling, 53(9), 1689-1699.

Hani, U. (2019). Pendidikan Kejiwaan

Dr.Abdullah Nashih 'Ulwan: Konsep

Dan Implementasinya. Jurnal Studia

Insania, $\quad 6(2)$,

90.

https://doi.org/10.18592/jsi.v6i2.2084

Ibda, F. (2012). Pendidikan Moral Anak

Melalui. Jurnal Ilmiah DIDAKTIKA, XII(2), 338-347.

Iskandar, E. (2017). Mengenal Sosok Abdullah Nashih Ulwan dan Pemikirannya tentang Pendidikan Islam (Bagian Pertama dari Dua Tulisan). Jurnal Akademia, XIII(1), 50-67.

Jamiludin Usman. (2018). Kaidah-Kaidah

Dasar Pendidikan Anak (Studi Komparasi Pemikiran Abdullah Nashih 
Ulwan dengan Maria Montessori). TADRIS: Jurnal Pendidikan Islam, 13(1),

https://doi.org/10.19105/tjpi.v13i1.171

6

Lubis, R. R. (2018). Optimalisasi

kecerdasan spiritual anak.

Optimalisasi Kecerdasan Spiritual Anak, I, 1-18.

Ma'zumi, M., Syihabudin, S., \& Najmudin, N. (2019). PENDIDIKAN DALAM PERSPEKTIF AL-QUR'AN DAN AL-SUNNAH : Kajian Atas Istilah Tarbiyah, Taklim, Tadris, Ta'dib dan Tazkiyah. TARBAWY: Indonesian Journal of Islamic Education, 6(2), 193-209.

https://doi.org/10.17509/t.v6i2.21273

Machmud, H. (2014). Urgensi Pendidikan Moral dalam Membentuk Kepribadian Anak. Jurnal Al - Ta'dib, 7(2), 75-84. Montanesa, D., Ahmad, R., Padang, U. N., \& Barat, S. (2021). EDUKATIF : JURNAL ILMU PENDIDIKAN Perbandingan Sistem Pendidikan Indonesia dan Jepang Kata Kunci: Sistem Pendidikan, Sistem Pendidikan Jepang, Sistem Pendidikan Indonesia . 3(1), 174-179.

Muhammad Takdir Ilahi. (2012).

Revitalisasi Pendidikan Berbasis

Moral. Ar-Ruzz Media.
Muhdi, A. (2018). Konsep Moral Pendidik dan Peserta Didik Menurut Imam Al Nawawi. Lontar Mediatama.

Nawawi, A. (2011). Pentingnya Pendidikan Nilai Moral Bagi Generasi Penerus. Jurnal Kependidikan: Insania, 16(2), 119-133.

c:/Users/asus/Downloads/1582-Article Text-3012-1-10-20180527.pdf

Palinggi, S., \& Ridwany, I. (2020). Peran Nilai-Nilai Moral Pancasila dalam Kemajuan Teknologi di Era Milenium. Seminar Nasional (SEMNAS) Pendidikan Bela Negara, March, 4853.

http://pgsd.umk.ac.id/files/prosiding/2 020/9_Sandryones_Hlm_48-53.pdf Rasimin, R., Yusra, A., \& Wahyuni, H. (2021). Penerapan Bimbingan Belajar Berbasis Prinsip-Prinsip Belajar dalam Islam untuk Meningkatkan Etika Belajar Siswa. Edukatif: Jurnal Ilmu Pendidikan, 3(2), 321-332. https://doi.org/10.31004/edukatif.v3i2. 262

Retno Dwiyanti. (2013). Peran Orang Tua Dalam Perkembangan Moral Anak (Kajian Teori Kohlberg). Prosiding Seminar Nasional Parenting, 161-169. Rukiyati. (2017). Pendidikan Moral di Sekolah. XVII(1). 